\title{
INSTITUTIONS AND EMPLOYMENT RELATIONS: THE STATE OF THE ART
}

\author{
Adrian Wilkinson and Geoffrey Wood
}

\begin{abstract}
Whilst the marginalisation of unions and the hegemony of neo-liberalism in many of the advanced societies challenged the raison d'etre of industrial relations, the revival of institutional approaches to political economy has underscored the relevance of a field of study where institutions have always been central. Whilst generated through failures in market regulation, the recent economic crisis has ironically, led both to pressures for a further paring back of governmental capabilities for regulation and enforcement, and a renewed interest in the possibilities for meaningful institutional redesign. This paper highlights main currents in contemporary institutionalist thinking and their relevance for the study of industrial relations. It introduces and locates the subsequent articles in this collection in the context of broader debates, and the relevance of their differing perspectives for advancing institutional analysis within and beyond industrial relations.
\end{abstract}

\section{Institutions and the Industrial Relations Tradition}

In studying work and employment relations, there has been a historical division into two distinct streams (Kaufman 2002, p94, ) The first, the broad personnel management argued that any labour issues were mostly about poor management and associated misunderstandings between players. The second, institutional labour economics were concerned with the manner in which imperfectly operating markets disadvantaged employees, and the persistence of a (ultimately premodern) master and servant relationship, which denied employees procedural and democratic rights (ibid, p94). These problems could only be solved at the institutional level through legislation, systemically embedded unions, full employment policies and adequate social protection (ibid, p94). Institutional labour economics gradually infused elements of sociology and political studies, and law, and "drifted away from the parent discipline” (ibid, p95).

Dunlop (1958) posited that industrial relations were about embedded rules; institutions provided stability, order and continuity. Critics such as Hyman (2002, p52) argued that this focus on order reflects an inherently conservative orientation, that ignores the possibility of conflict and contradictions. In Dunlop's defense, it should be noted that he was writing at a time when, within most advanced societies, there was a political consensus on the need for institutional mediation between competing interests, and when, even in liberal markets, genuine social tradeoffs were more the norm than the exception. More salient is the criticism that his systems approach focuses on organisation, when there has been a growing individualisation of employment relations (Hyman 2002, p52). Again, a focus on formal rules ignores the importance of informal conventions (Jessop 2001a; Sisson 2010). A further limitation is that much is said about the role of institutions as underpinning order, but little about the often traumatic historical circumstances under which institutions are bedded down, and indeed, when they are remade (Ackers and Wilkinson 2008). Additionally there is a considerable gap between saying that institutions matter, and generating testable hypotheses as to what their precise effects may be where (Kelly 1998, p42).

\section{Rational Choice Approaches and Institutions}


As Peters (2005, p20) notes, rational choice approaches see institutions as giving rules and inducements, informing the choices of utility maximizing individuals. From a neo-classical economics perspective, institutions would be seen as distorting the smooth operation of markets. Neo-institutional rational choice accounts share this concern, that inappropriate institutions may prompt 'wrong' or sub-optimal choices. However, they also hold that institutions can be efficient, reflect rationality and provide the sort of incentives necessary to make optimal choices; in other words, rationality combines with setting, making for outcomes that are dependent on the context (Djelic 2010, p2529). This may suggest a 'watering down' of the focus on rational actors encountered in mainstream economics (ibid, p29). However, in practice, they have centered on the extent to which institutions protect private property rights, or fail to do so (North 1990; La Porta et al 1998, 2000). What characterizes this approach is an emphasis on strong path dependence, and on the existence of institutional ideal types worth emulating; more specifically, the liberal market framework, centering on the common law legal tradition (La Porta et al 1998, 2000). Such work assumes that institutions 'work'; in other words, that compliance and adaption of behaviour is more common than outright evasion. Particularly influential has been the work of La Porta and colleagues, focusing on legal origin, owner rights and economic performance

This work was later broadened to explore the impact of worker rights, which were depicted as incompatible with, and inherently weakening, owner rights; in practice, nations tended to be distinguished by relative variations of both, but with strength in one area being associated with a weakness in the other (Botero et al 2004). In short, worker rights are bad for firms. Indeed, it was argued that workers would ultimately benefit from stronger owner rights, as firms would prosper, and those most productive and effective workers would gain their due rewards, or reap benefits elsewhere through the efficient operation of deregulated external labour markets (Botero et al 2004). This, of course, would be an anathema to the bulk of mainstream industrial relations scholarship, who would point to the fact that many firms found their competitiveness on sustained labour repression (Gall et al 2011). Moreover, the assumptions of sustained systemic functionality, and that the 'most rational' institutional frameworks are stable and immune from contestation, would ignore both the great volatility of the most lightly regulated markets, and the mobilization and resistance that is associated with long term changes in capitalism (see Kelly 1998). But, if this perspective has been contested by scholars with an interest in industrial relations (Cooney et al 2010; Deakin and Sarkar 2008), it has had considerable policy and practical influence. More specifically, the World Bank Doing Business Project has aggressively promoted the notion that weak worker rights make for a good environment to do business: that countries should accordingly roll back labour law (Cooney et al 2011) This means that whilst industrial relations scholars may dispute the theoretical foundations of this approach, its impact on industrial relations practice is likely to be considerable, particularly within those countries dependent on International Financial Institutions.

\section{Organisational-Societal Approaches}

In a particularly influential 1983 essay, DiMaggio and Powell (1983) argued that, rather than for profit maximizing reasons, actors choose to follow institutional rules for reasons of legitimation. Organisations reproduce 'taken for granted' and embedded cognitive assumptions as to what is desirable (Whitley 1999, p13). Within the employment relationship, it is desirable for managers and owners to at least have some legitimacy within the eyes of their workforce: outright coercion is inefficient and with uncertain outcomes. From the side of employees, acting within broad rules 
and conventions that are seen as 'reasonable' and 'fair' makes them better equipped to enforce mutually agreed rights. Again, in their interactions with other firms and actors, cooperation is facilitated through mutual notions of legitimacy. Hence, within a particular social context, industrial relations practices within individual firms (whether locals or multinationals) will become 'isomorphic' within dominant institutional frameworks.

In seeking to understand institutional building and change, they argue that this takes place when actors have a strong interest in a particular institutional framework (DiMaggio and Powell 1988). Critics have argued that this juxtaposes external institutional constraints and theories of rational strategic resource mobilisation (Djelic 2010, p681). Streeck (2010, p681) argues that seeking to rewrite the rules for one's own interest is likely to undermine existing solidarities and ties, and be an 'act in bad faith'. In other words, if players require legitimacy, rewriting the rules to favour their interests is likely to undermine this: in short, in seeking to legitimise certain types of behaviour, the basis of their existing and potential legitimacy is undermined. Or, as Jackson (2010, p70) notes, actors are depicted by rational choice economics as rule makers, enacting institutions in order to optimise choices and outcomes. The structuralist sociological tradition has tended to see actors as rule takers, in other words, in following on conventions, norms and rules (ibid.). DiMaggio and Powell's work rather conflates this approach.

\section{Varieties of Capitalism Approaches}

The early Varieties of Capitalism literature sought to explain the relatively superior performance of Germany and Japan when compared to Liberal Market Economies (LMEs), such as Britain and the United States in the 1980s; particularly when it came to manufacturing and the export of manufactured goods (see Lincoln and Kalleberg 1990). It was argued that this reflected specific institutional frameworks that encouraged cooperative work and employment relations (ibid). The recovery of liberal markets by the early 2000s - even if they were still associated with poor performance in manufacturing - led to a shift in much of the literature to a rather more neutral position. Whilst Dore (2000) made the case for the intrinsic superiority - both in performance and moral grounds - of stakeholder capitalism and associated cooperative work and employment relations over shareholder capitalism, a particularly influential collection by Hall and Soskice (2001) suggested that no system was intrinsically superior. Rather specific sets of national configurations made for specific sets of complementarities in both rules and practices, favouring certain types of economic activity over others. Thus, for example, within liberal markets, good generic tertiary education and weak tenure enabled skills and knowledge to be diffused across organisations than would otherwise be possible in a situation of adversarial competition (Thelen 2001): highly mobile investor capital enables innovative startups. Again, within Coordinated Markets (CMEs) many firms found their competitiveness from regulations that underpin cospecific assets shared with workers, such as industry specific skills bases and knowledge (Hall and Soskice 2001). Hall and Soskice (2001) held that firms will seek to hang on to or restore the institutional basis of their competitive advantage after external shocks; in most cases, coordination can be restored (ibid, p65).

In short, what characterised this literature was both an emphasis on continuity and parsimony in analysis. Ultimately, within the advanced societies, most countries fell into or close to the LME or CME archetype. The Hall and Soskice (2001) collection owed its particular influence to this: not only did it allow for simplicity in analysis, but, it emphasised the relative durability and viability of the CME model in the face of neo-liberal attacks. In terms of the specific industrial 
relations features associated with each model, Hall and Soskice (2001) concentrated on broad brushstrokes, but specific contributors to the collection highlighted specific characteristics of work and employment relations, and of labour markets that were particularly associated with one capitalist archetype or another.

A number of criticisms can be advanced against this approach. First, as Weiss (2010) notes, whilst the US is held up as the quintessential LME, in many areas, the US state is highly interventionist. More specifically, the hi-tech and defense industries rely heavily on state protection, support, and in the case of the latter, highly beneficial government contracting (ibid). The R\&D base of these sectors is partially underwritten by the state and not-for-profit university sectors. Indeed, it could be argued that the other archetypical area of economic activity encountered in the US, the low value added service sector, also bears the imprint of statism. Workfare policies help secure and discipline low cost unskilled labour (Peck 2001). The penalisation of over two million of the poor both helps underpin social order and mask unemployment; the large military also helps mop up excessive numbers of the redundant poor. In short, liberal markets may be both characterised by a great deal of formal and informal regulation, and be internally diverse. One can identify at least two archetypical work and employment paradigms. The first, encountered in the hi-tech sector would be about contingent working, but also about high levels of generic knowledge, the linking of individual fortunes to organisational fortunes through share offerings, individual bargaining where the employee has meaningful skills and knowledge to bargain, and relatively good wages (see Wright and Dwyer 2006). The second, encountered in the low-end sector, would be characterised by poor wages, contingent working interposed with periods of unemployment or sub-employment, wages being set at the legal minimum or substance level, and highly unequal individual bargaining (ibid).

\section{Historical Institutionalism}

Historical institutionalism suggests that institutions are structural frames, which are bedded down and entrenched at specific times (Djelic 2010). In short, a formative event, trauma or crisis leads to institution building then consolidation. The resultant coordination is a political process that requires constant nurturing, renegotiation, or simply patching up (Thelen 2010). This reflects conflict inherent in the system, not only between employers and employees, but also between firms and other associations, and between different firm types. Institutions do not reflect a single, but rather many different logics and principles of rationality (Jackson 2010). The latter reflects historical compromises. Given that the latter are likely to face constant strains and pressures, their reconstitution is a political process. Whilst it would be incorrect to say institutions have a specific shelf life, the longer institutional arrangements remain in place, the more likely they are to be over-turned.

In his classic 'old institutionalist' writings, Polanyi (1944) talked of a double movement. At specific times, unrestrained capitalist interests gain the upper hand; this leads to a reaction in order to reign in the destructive features of markets. In turn, comprehensive regulation will bring with it tensions of its own, leading to a countermovement back to the deregulation of markets. Where contemporary historical institutionalism differs from this is that they see this process as both meandering and temporarily specific (Streeck 2010). The move from one pole to the other is not linear, and markets and regulations assume different forms at different times. In other words, it is not possible to rebuild or recapture the social compromises of the past, whilst in different settings, markets introduce both specific pathologies and strengths. What does this mean for the 
study of industrial relations? One can neither assume that great systemic distortions or failures will right themselves, and that once broken down, historical compromises cannot be reconstituted. A progressive double movement deus ex machine will not automatically arise out of the failures of neo-liberalism, but neither is the neo-liberalism indefinitely sustainable in the face of persistent market failure. New compromises are certainly possible, but so is a sustained period of contestation, of disorder or meandering prior to the bedding down of a new compromise.

\section{Regulation Theory}

Of all the institutional approaches, the mainstream regulationist approach devoted the most specific attention to the articulation between institutions and firm level work and employment relations practice. Regulationist theory concerns itself with both an accumulation regime, and dominant associated mode of regulation (ie the institutions that mediate, stabilise and make growth possible), both of which are temporarily specific, mediated by class conflict, and endow specific stages of capitalism with their own patterns and structural crises (Jessop 2001a, pxiv). Accumulation regimes not only embody the dominant production paradigm, but also wage distribution and relative inequality, demand and the time horizons of investment decisions (Boyer 2001, p106). A major critique of early regulation theory was, in its concern with the structural crises of Fordism, neglecting the nature of diversity with the latter, and the importance not only of temporal, but also spatial specificality. As Jessop (2001b, p55) notes, Fordist regional economies and clusters of other types of production paradigm can be encountered within the same national setting, whilst in some national contexts, 'purer' forms of Fordism were encountered during the long boom (ibid).

What does this mean in practice? To regulationists, classic Fordism was associated not only with mass production, but also a relatively fairer distribution of wages and incomes than would be encountered in much of the contemporary world. The limits of such a relatively homogenised view of the past notwithstanding (a limit now acknowledged by mainstream regulationist theorists), this does still underscore the point that, in many contexts, wages, tenure and working conditions have deteriorated or stagnated for a large component of the workforce, and this is bound up with the inherent instability across the global economy over the past forty years. Indeed, this has led some writers to argue that neo-liberalism is not a functional accumulation regime at all (Wolfsson 2003).

More recent regulationist concerns have shifted to the issue of systemic change. More specifically, change may be about institutional substitution, hybridisation or experimentation (Boyer 2006). There is much common ground with this and contemporary historical institutionalism (Streeck 2010), and would point to the extent to which both the reality of, and changes to, dominant work and employment relations paradigms and associated institutions is a messy, complex and contested process. In contrast, the Varieties of Capitalism approach has emphasised systemic coherence and parsimony in defining features (Jessop 2011).

Jessop (2011) argues that rather than historical institutionalism or the Varieties of Capitalism approach, the contemporary order may best be understood as variegated capitalism. By this it is meant that whilst there are many nationally specific different forms of capitalism, one type of order assumes predominance within the global capitalist ecosystem at any particular times. This would explain why there are common trends in contemporary work and employment to less 
secure and contingent working, greater social inequality and weaknesses in organised labour. Many developed societies are neither liberal markets nor neo-liberal, but all have had some contagion from neo-liberalism. Reflecting this, central concerns of the mainstream industrial relations literature have been with union decline, instability and rising inequality within and beyond the workplace. Drawing on the Marxist tradition, Jessop (2011) adds that "within rational capitalism, only the expenditure of socially necessary labour power in commodity production generates value (and hence the potential for profit) for capital as a whole”. This would highlight the vital distinction between the activities of rentiers and productive capital, and the extent to which the relative enhancement of the power of the former within the global ecosystem is likely to be a symptom of crisis and decay, rather than the basis for stable and sustainable growth.

\section{Business Systems Theory}

Whitley (1999) shares the view of Hall and Soskice (2001) that contractual relations depend on embedded formal and informal rules. Business systems theory explicitly sets out to develop a comprehensive framework for comparing systems of economic coordination and control, and associated firm practices (Whitley 1999, p15),. More specifically, Whitley (1999) argues that one of the defining features of distinct business systems is employer-employee interdependence and delegation. The former involves variations in security of tenure, and in investments in skills and developments. The latter, meanwhile, concerns employee voice (ibid.). The main criticism that can be leveled at this approach (in addition to the omnipresent question as to the desirable number of capitalist archetypes) is how the other defining features of capitalism are identified, and the empirical foundations of differentiation. In contrast, Amable's (2003) rather more inductive approach accords a more detailed focus, inter alia, on specific features of the industrial relations environment, encompassing issues such as variations in collective bargaining and unionisations, and in social protection, and derives his different country categories via cluster analysis. Amable's account however, is rather more directly within the broad regulationist literature, and hence, is less concerned with long term continuities than Whitley's.

\section{Recent Developments}

Recent work has sought to shed further light on the nature of systemic diversity and change. More specifically, there is a growing recognition that institutions are not as closely coupled as often depicted, and that within national contexts, it is likely that not one, but several dominant work and employment relations paradigms are likely to be encountered (Barry and Wilkinson 2011; Wilkinson 2008). Lane and Wood (2010, ) argue that internal diversity within national institutional reflects the product of four factors: social action, complementarity, systemic change, and sub- and supra national configurations.

It is argued that national institutional arrangements are constantly developing in a non-linear manner, and never can be made to assume the precise form or function as at the time of original design (Lane and Wood 2010; Lane and Wood 2010, Boyer 2006). This reflects the choices of social actors who, in enacting and contesting specific frameworks, seek to bend structures to suit specific needs, and, in interpreting rules and procedures, invariably impart an element of subjectivity. Complementarity represents both the introduction and clustering of rules and practices both to build on systemic strengths and compensate for weaknesses (Crouch 2005): this process of adjustment may assume a regional and / or sectoral dimension. Finally, in exploring systemic change, it is argued that long term transitions tend to favour owners of more fungible 
assets over those with less (Lane and Wood 2010). Rentiers benefit from periods of instability than more long term investors, and the associated increased deployment of contingent labour erodes the position of more secure categories of labour (Pollin 2007). This has led Standing (2011) to argue that there has been the rise of a global precariat of insecure and poorly paid workers, many of whom are in the process of migrating within and across national boundaries: such workers lack the security of regular incomes, stable occupational identities and even of spatial rootedness. This process is at once is both functional and dysfunctional for existing institutional frameworks. Highly vulnerable workers are more easily disciplined (particularly illegal immigrants), and play a central role in many national economies: they are voiceless, lack meaningful regulatory protection, and, in the case of illegals, face the omnipresent threat of being denounced to the authorities and deported (Standing 2011). However a shifting, and expanding, global underclass challenges the capabilities and legitimacy of national authorities, and indeed, potentially of the existing global order (ibid).

\section{Theoretical Trends and Applied Insights - Development and Syntheses}

Our papers in this issue are diverse but stimulate debate within this area.Colin Crouch explores employment, consumption, debt and European industrial relations systems. The crisis showed that the Anglo-American economies had become dependent on high and unsustainable levels of household debt among workers on moderate incomes to maintain their growth model. Hence the deregulated finance system had been associated with economic success, not simply by having a role in improving economic efficiency, but in enabling workers with insecure jobs and static real wages to keep spending. He points out that recent comparisons between British and German employment performance years have characterized the two countries as, respectively, one of high employment based on high consumption expenditure financed by household debt, and one tied to an external trade and low consumption model that no longer creates jobs. However by placing these two countries in the context of all European Union member states and the USA we see a different picture. He finds two different patterns are associated with high employment levels: a northern European one of low consumption expenditure and high household debt, and an Anglophone one of high consumption expenditure and high household debt. Explanations for these contrasting models can be found in their different social policy and industrial relations systems.

Kristensen and Morgan argue that institutionalist analysis needs to move away from the fixed categories on which it has depended in the past towards a notion of the mutual constitution of actors and institutions. By developing the concepts of experimentalism at the level of the firm and the institutions they provide a framework to analyse institutional change. Whilst recognising the contribution of the regulation school, they work from the capabilities of actors within firms to develop and experiment with their own solutions to economic problems by reconstituting institutions. The case of Denmark shows how one society has moved towards experimental institutions. They emphasise that in the current context of globalisation, firms and actors within firms are continuously developing the way in which they organise work and employment in order to produce goods and services which are competitive in global markets. This creates a pressure for institutional change to facilitate the process of firm level experimentation and it also tends to create a pressure for new experimental forms of institutions This change calls for extending the study of Industrial Relations to investigating how new dynamic complementarities between employees, managers, institutions and markets are created and the effects of these processes on employment growth, on income inequalities, on 
inequalities between groups, on rights at work and on the distribution of skills and autonomy in the workplace.

Bruce Kaufman's paper uses institutional economic theory drawing from Commons and Coase, to examine the purposes, economic effects and social welfare consequences of labor unions. Cross-discipline and cross-national principles of the institutional paradigm are described, the American and European literatures are briefly juxtaposed, and the subject of unions in place in a larger paradigm context. Relative to previous studies, this paper presents the most formal and analytically developed application of institutional theory to the subject of unions. A number of new or revisionist implications are developed as are contrasts with neoclassical-based models. While institutional theory has not been widely utilised in IR in the US, Kaufman points to roots in early American institutional economics (IE), particularly the Wisconsin School version pioneered by Commons. The disciplinary orientation and mode of analysis in this paper are more economic and micro-focused than the norm but it provides an example of institutional theory in action and demonstrates how the paradigm can be applied in a relatively formal and analytical way to a core subject area in labor economics and IR.

Jackson points out that theories of industrial relations have called for a stronger integration of the economic and social. Whereas economists have studied economic functions of institutions, neoinstitutional approaches in sociology have strongly rejected economic explanation in favour of seeing institutions as taken-for-granted cognitive assumptions. In order to further dialogue among these perspectives, he reconstructs the concept of institutions in thel sociological theory of Durkheim and Weber. In order to progress a more theoretically integrated approach to understanding institutions, he returns to the classical sociological writing of Durkheim and Weber. While Durkheim stressed the function of institutions for the social integration of individuals, Weber saw institutions as embodying different sets of values and rationalities across various domains of society. Despite their distinct emphasis on the functional or value-rational aspects of institutions, the tensions between economic functions and social values remained an explicit focus of both Durkheim and Weber.

Castilla notes growing interest in how key employer practices have changed the organisation of work but note that the gender and racial implications of such practices are neglected . Using unique longitudinal personnel data from one large organisation, he takes a comprehensive sequential approach to identify the use of merit-based reward programs to evaluate and reward workers and that gender and racial disparities may exist. The analyses show that there are significant gender and racial differences at the performance evaluation, salary, and career setting stages, even after implementing these merit-based work practices. He conclude by discussing the implications for how and where current organisational practices and work arrangements may affect the careers of women and racial minorities in the contemporary workplace.

Dibben and Williams point out that the varieties of capitalism and employment relations literature has largely focused on formally regulated market economies, with a general neglect of the informal economy and of emerging markets where this work arrangement is dominant. They propose the Informally Dominated Market Economy as a form of capitalism that could be usefully incorporated into the industrial relations literature. To start to unpack this variety of capitalism, this article explores institutions and employment relations practices in the African 
economy of Mozambique. The outcome is a conceptual framework that includes both formal and informal institutions and considers the implications for work and employment relations.

Wright et al explores the impact of Private Equity (PE) firms on human resource management practices in buy-outs using data drawn from the a representative pan-European survey . The findings suggest the overall impact of PE on High Performance Work Practices (HPWP) is affected more by length of the investment relationship than the countries where PE is going to or is coming from. PE investment results in the increased use of HPWP in buy-outs the longer the anticipated time to exit. With respect to the PE firms' country of origin, buy-outs backed by Anglo-Saxon PE firms are as likely to introduce new HPWP (and are specifically more likely to extend performance-related pay schemes) as those backed by non-Anglo-Saxon PE firms, suggesting some adaptation to the local host country contexts of buy-outs.

Finally Richard Croucher examines management and labour process changes in a Moldovan factory to examine their impact on the trade union as institution. Changes in management structures and work organisation have hollowed out key legacies, notably the 'labour collective' and informal bargaining, and evoked resistance from workers. The union is disconnected from worker resistance and is faced with major issues concerning its role. They conceptualise it as a 'suspended institution'. ). It is 'suspended' because its principal support, a necessary condition of its survival, is from above. Stripped of the complementary institution of the labour collective and disconnected from workers' resistance to the new production régime, it has little or no support from its putative constituency. It is also suspended from the reality of workers' lived experience in the productive process. Its position is also suspended in a third, historical, sense, in that it , owies its existence to the reaffirmation of a previous tradition without having set in train any measures to reform itself but he comments that it would be inadequate to simply conceptualise it as 'residual' or 'hollow Management now has no mechanism beyond dismissal to deal with low motivation, labour turnover, indiscipline and small scale industrial action. The possibility of management allowing the union to adopt some representative function in response to worker demand cannot be excluded and it is also possible that an alternative union leadership might emerge from below to connect worker resistance to the union.

\section{Conclusions}

Whilst it can be argued that no understanding of work and employment is complete without taking account of the interplay of practice with institutions, the linkages are by no means always closely articulated.(Wilkinson and Townsend 2011) From within the radical political economy tradition, the relationship between the physical and social process of production and wider societal institutions is central. However, as Thompson and Smith (2010, p22) note, much of the labour process literature has remained focused on a 'plant based' approach, with 'some sensitivity' to the wider socio-economic framework. Within regulation theory, whilst again there is an implicit connection drawn between work and employment relations, and institutions, much of recent regulationist literature has focused on macro-societal issues, drawing implicit, rather than explicit connections to changes and continuities in the employment relationship.

Again, the early literature on comparative capitalism specifically drew links between particular work and employment relations paradigms, and wider institutional realities (Lincoln and Kalleberg 1990; Dore 2000). However, from Hall and Soskice (2001) onwards, there has been a focus either on broad trends, and the often anecdotal presentation of case study evidence, but 
with a stronger emphasis on the political rather than broader crises within the global capitalist economy (Thompson and Vincent 2010, p58).

It is perhaps Bob Jessop's recent work on variegated capitalism that comes closest to resolving this issue, through the abovementioned distinction between the wider capitalist ecosystem and what takes place within specific national contexts. However, Jessop's work is closer to the regulationist tradition; his primary engagement with the varieties of capitalism literature is at the level of critique.

Business systems theory does make very implicit connections between the key dynamics of work and employment and context (Whitley 1999), although in recent years, this focus has shifted towards concerns such as the multinational corporation (c.f. Morgan 2010). Historical institutionalists have sought to resolve this concern, albeit through a stronger focus on social action (Thompson and Vincent 2010), which in practice, remains often at the level of formal association than in terms of the contradictions and contestations that characterise working life, whether unionised or not.

What this collection seeks to do is bring back institutions into how we understand work and employment relations, and vice versa, through focusing more closely on the articulations. 


\section{References}

Amable, B. (2003), The Diversity of Modern Capitalism, Oxford University Press

Ackers P and Wilkinson A (2003)

Ackers P. and Wilkinson A. (2008) 'Industrial Relations and the Social Sciences', in P. Blyton, N. Bacon, J. Firito and E. Heery (eds) The Sage Handbook of Industrial Relations. London, Sage. pp53-68

Barry M. and Wilkinson A. (eds) (2011) Handbook of Comparative Employment Relations. London, Edward Elgar

Botero J., Djankov S., La Porta R., Lopez-de-Silanes S. and Shleifer A. (2004) 'The Regulation of Labor', Quarterly Journal of Economics, Vol.119, 1339-82

Boyer R. (2001) 'The Eighties: The Search for Alternatives to Fordism', Regulationist Perspectives on Fordism and Post-Fordism - Regulation Theory and the Crisis of Capitalism Volume 3. Cheltenham, Edward Elgar

Boyer R. (2006) 'How do Institutions Cohere and Change', in G. Wood and P. James (eds) Institutions and Working Life. Oxford, Oxford University Press

Cooney S., Gahan P. and Mitchell R. (2011) 'Legal Origins, Labour Law and the Regulation of Employment Relations', in A. Wilkinson and K. Townsend (eds) The Future of Employment Relations: New Paradigms, New Developments. London, Palgrave Macmillan

Crouch C. (2005) 'Three Meanings of Complimentarity', Socio-Economic Review, Vol.3, No.2, 359-63

Deakin S. and Sarkar P. (2008) 'Assessing the Long-Run Economic Impact of Labour Law Systems: A Theoretical Reappraisal and Analysis of New Time Series Data', Industrial Relations Journal, Vol.39, 453-87

DiMaggio P.J. and Powell W. (1983) 'The Iron Cage Revisited: Institutional Isomorphism and Collective Rationality in Organizational Fields', American Sociological Review, Vol.48, 147-60

DiMaggio P.J. and Powell W. (1988) 'Interest and Agency in Institutional Theory’, in L. Zucker (ed) Institutional Patterns and Organizations. Cambridge, Ballinger 
Djelic M.-L. (2010) 'Institutional Perspectives - Working Towards Coherence or Irreconcilable Diversity', in G. Morgan, J. Campbell, C. Crouch, O.K. Pederson and R. Whitley (eds) The Oxford Handbook of Comparative Institutional Analysis. Oxford, Oxford University Press

Dore R. (2000) Stock Market Capitalism: Welfare Capitalism. Cambridge, Cambridge University Press

Dunlop J. (1958) Industrial Relations Systems. New York, Holt-Dryden

Gall G., Wilkinson A. and Hurd R. (eds) (2011) Handbook of Labour Unions. London, Edward Elgar Press

Hall P. and Soskice D. (2001) 'An Introduction to the Varieties of Capitalism' in P. Hall and D. Soskice (eds) Varieties of Capitalism: The Institutional Basis of Competitive Advantage. Oxford, Oxford University Press

Hyman R. (2002) 'What is Industrial Relations?', in J. Kelly (ed) Industrial Relations Critical Perspectives on Business and Management. London, Routledge

Jackson G. (2010) 'Actors and Institutions', in G. Morgan, J. Campbell, C. Crouch, O.K. Pederson and R. Whitley (eds) The Oxford Handbook of Comparative Institutional Analysis

Jessop B. (2001a) 'Series Price', Regulationist Perspectives on Fordism and PostFordism - Regulation Theory and the Crisis of Capitalism Volume 3. Cheltenham, Edward Elgar

Jessop B. (2001b) 'Introduction', in B. Jessop (ed) Regulationist Perspectives on Fordism and Post-Fordism - Regulation Theory and the Crisis of Capitalism Volume 3. Cheltenham, Edward Elgar

Jessop B. (2011) 'Rethinking the Diversity and Variability of Capitalism: on Variegated Capitalism in the World Market', in C. Lane and G. Wood (eds) Capitalist Diversity and Diversity within Capitalism. London, Routledge

Kaufman B. (2002) 'The Origins and Evolution of the Field of Industrial Relations in the United States', in J. Kelly (ed) Industrial Relations - Critical Perspectives on Business and Management. London, Routledge

Kelly J. (1998) Mobilization, Collectivism and Long Waves. London, Routledge 
Lane C. and Wood G. (2010) 'Institutions, Internal Diversity and Change', in C. Lane and G. Wood (eds) Capitalist Diversity and Diversity within Capitalism. London, Routledge

Lane C. and Wood G. (2009) 'Diversity in Capitalism and Capitalist Diversity', Economy and Society, Vol.38, No.4, 531-51

La Porta R., Lopez-de-Silanes F., Shleifer A. and Vishny R. (1998) 'Law and Finance', Journal of Political Economy, Vol.106, 1113-55

La Porta R., Lopez-de-Silanes F., Shleifer A. and Vishny R. (2000) 'Investor Protection and Corporate Governance’, Journal of Financial Economics, Vol.58, 3-27

Lincoln J. and Kalleberg A. (1990) Culture, Control and Commitment: A Study of Work Organization in the United States and Japan. Cambridge, Cambridge University Press

Morgan G. (2009) 'Globalization, Multinationals, and Institutional Diversity', Economy and Society, Vol.38, No.4, 580-605

North D.C. (1990) Institutions, Institutional Change and Economic Performance. Cambridge, Cambridge University Press

Peck J. (2001) Workfare States. New York, Guilford Press

Polanyi K. (1944) The Great Transformation: The Political and Economic Origins of Our Time. Boston, Beacon Press

Pollin R. (2007) 'Resurrection of the Rentier’, New Left Review, Vol.46, 140-53

Sisson K (2010) Employment relations matters. . Available at http://www2/warwick.ac.uk/fac/soc/wbs/research/irru

Standing G. (2011) The Precariat: The New Dangerous Class. London, Bloomesbury

Streeck W. (2010) 'Institutions in History: Bringing Capitalism Back In’, in G. Morgan, J. Campbell, C. Crouch, O.K. Pederson and R. Whitley (eds) The Oxford Handbook of Comparative Institutional Analysis. Oxford, Oxford University Press

Thompson, P. and Vincent, S. (2010) 'Beyond the boundary: Labour process theory and critical realism’, In Thompson P, Smith C (eds.) Working Life: Renewing Labour Process Analysis . Basingstoke : Palgrave 
Thompson P and Smith C (2010) The State of the Labour Process Debate after 25 Years in In Thompson P, Smith C (eds.) Working Life: Renewing Labour Process Analysis . Basingstoke : Palgrave

Townsend K. and Wilkinson A (eds) (2011) Work and Employment Relations in the 21st Century. London, Edward Elgar Press

Whitley R. (1999) Divergent Capitalisms: The Social Structuring and Change of Business Systems. Oxford, Oxford University Press.

Wilkinson A. (2008) 'Industrial Relations', in S. Clegg and J. Bailey (eds) Encyclopedia of Organizational Studies, London, New York, Sage. pp. 652-53

Wilkinson A. and Townsend K. (eds) (2011) New Directions in Employment Relations. London, Palgrave

Wolfson M. (2003) 'Neo-liberalism and the Social Structure of Accumulation', Review of Radical Political Economics, Vol.35, No.3, 255-63

Wright E. and Dwyer R. (2006) 'The Pattern of Jobs Expansion in the USA', in G. Wood and P. James (eds) Institutions and Working Life. Oxford, Oxford University Press 